\title{
Isolation and characterization of bioactive compounds from Euphorbia cotinifolia
}

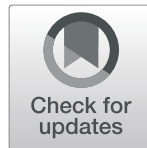

B. Jayalakshmi ${ }^{*}$, K. A. Raveesha ${ }^{2}$ and K. N. Amruthesh ${ }^{3}$

\begin{abstract}
Background: Green plants are found to be an effective reservoir for bioactive molecules and can provide appreciable sources of antimicrobial agents. Antibacterial activity of solvent extracts of Euphorbia cotinifolia leaves was tested by agar cup diffusion and broth microdilution methods against some common human pathogenic bacteria viz., Bacillus cereus, Klebsiella pneumonia, Enterobacter aerogenes, Escherichia coli, Staphylococcus aureus, Bacillus subtilis, and Salmonella typhi. The methanol extract of Euphorbia cotinifolia was subjected to a silica gel column, leading to the isolation of a bioactive compound 1 . The structure of compounds was elucidated by spectroscopic techniques and assessed for their antibacterial activity against several human pathogenic bacteria.

Results: The inhibition zone ranged against some common human pathogenic bacteria was $15.25-19.50 \mathrm{~mm}$, 13.50-19.25 mm, 12-18.50 mm, 15-20 mm, and 13-19 mm for ECMF1, ECMF2, ECMF3, compounds 1, respectively. The MIC was found to be in the range $91-729 \mu \mathrm{g} / \mathrm{ml}$ for the fractions. The inhibition range was recorded between 12-19 and 10-14 mm for methanol and ethyl acetate extracts, respectively. K. pneumoniae, E. aerogenes, and B. subtilis were highly susceptible to methanol extract with the maximum inhibition zone of $19 \mathrm{~mm}$. The MIC of the compound 1 against human pathogens was $78-833 \mu \mathrm{g} / \mathrm{ml}$.

Conclusion: The present study results suggest that tested plant extracts have moderate to potent antibacterial activity due to the occurrence of phenols and flavonoids in the extracts. The defensive property of natural antibacterials is mainly due to the presence of these major groups, vitamins, phenols, flavonoids, and carotenoids. In the present study, biologically active diterpene was isolated and the structures of the new diterpenoids isolated from E. cotinifolia were closely related to an ingenol ester.
\end{abstract}

Keywords: Euphorbia cotinifolia, Isolation, Antibacterial activity, MIC

\footnotetext{
* Correspondence: jayalakshmib74@gmail.com

${ }^{1}$ Post Graduate Department of Botany, Maharani's Science College for

Women, Mysore, Karnataka 570 006, India

Full list of author information is available at the end of the article
}

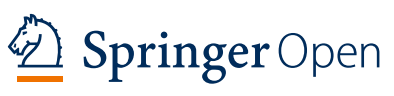

(c) The Author(s). 2021 Open Access This article is licensed under a Creative Commons Attribution 4.0 International License, which permits use, sharing, adaptation, distribution and reproduction in any medium or format, as long as you give appropriate credit to the original author(s) and the source, provide a link to the Creative Commons licence, and indicate if changes were made. The images or other third party material in this article are included in the article's Creative Commons licence, unless indicated otherwise in a credit line to the material. If material is not included in the article's Creative Commons licence and your intended use is not permitted by statutory regulation or exceeds the permitted use, you will need to obtain permission directly from the copyright holder. To view a copy of this licence, visit http://creativecommons.org/licenses/by/4.0/. 


\section{Background}

Natural products from plants serve as a vast source of compounds with amazing chemical and functional diversity and make significant contributions to drug development programs. A great deal of research has been throughout the world to isolate the secondary metabolites from natural resources [1]. During recent years, extensive attention has been directed towards the exploitation of plant products for the control of different microbial infestations [2]. Since ancient times, man has utilized plants to treat many common infectious diseases and some of these traditional practiced medicines are still used as part of the habitual treatment of various maladies. Despite the possibility of different methods for the discovery of therapeutics, natural products still remain as one of the best reservoirs of new compounds. The use of plant extracts and phytochemicals, both with known and unknown antimicrobial properties, is of great importance to therapeutic treatments. Many medicinal plants are considered to be rich in antimicrobial crude drugs and also as a source for novel compounds with biological activity, with possibly many new modes of action [3].

Euphorbiaceae family plants are well known for the chemical diversity of compounds especially their isoprenoid constituents, and diterpenoids in the majority of the genus having many different skeletons such as tiglianes, jatrophanes, ingenanes, lathyranes, myrstinanes, sesquiterpenoids, flavonoids, and steroids were also obtained. In addition, the isolated compounds from the genus Euphorbia extracts have exhibited different biological activities [4]. There are several reports of antibacterial activity of several euphorbia species. A study of phytochemical and antibacterial activity against human pathogens of ethanolic extracts of some Euphorbiaceae members such as Euphorbia milii, Euphorbia hirta, Euphoria pulcherrima, Euphorbia tithymaloides, and Euphorbia prostrata reported maximum activity against all the bacterial strains where Euphorbia milii showed a zone of inhibition of $10 \mathrm{~mm}$ [5]. The study of antibacterial properties of flavonoids of leaves from different cacti (Euphorbia caducifolia) against some important bacteria ( $\mathrm{G}+$ ve or $\mathrm{G}-\mathrm{ve})$ and reported that they possess strong antibacterial activity against test pathogenic microbes and revealed $7.83 \pm 0.21 \mathrm{~mm}$ zone of inhibition for free flavonoid [6]. The petroleum ether and methanolic and aqueous extracts of leaves of Euphorbia hirta recorded antimicrobial activity against B. subtilis, E. coli, S. aureus, and $S$. cerevisiae, and all the extracts revealed moderate to significant activity in contrast to standard. The phytochemical analysis of petroleum ether and methanolic and aqueous extracts revealed the presence of tannins, related polyphenols, terpenes, anthocyanins, alcohols, steroid-like ß-sitosterol, and $ß$-amyrin [7].The above studies reported the potential of Euphorbiaceae plants. In the present research, Euphorbia cotinifolia Linn. (Caribbean copper plant) was considered for the study. The common name for the species includes smoke tree spurge, Caribbean copper plant, and tropical smoke bush. E. cotinifolia is a tropical shrub or small tree with thin leaves deciduous that is prominent for its attractive burgundy-red foliage. The Euphorbia genus belongs to the family Euphorbiaceae that comprises at least 2100 species and is one of the most diverse genera in the plant kingdom [8]. Euphorbia cotinifolia is a deciduous tropical shrub possessing many medicinal applications. The leaves of the plant had been employed as poison for catching fish by Southern American Indians. The latex is strongly purgative and the leaves have molluscicidal and antiviral properties [9]. Hirota et al. have worked on the extract of $E$. cotinifolia leaves resulting in isolation and characterization of some ingenol-esters such as 3-O-propionyl-20-O-(S)-(2'-methyl)butyryl-ingenol, 20-O-isobutyryl-ingenol, 3-Opropionyl-20-O-isobutyryl-ingenol, and 3,20-O-di-isobutyryl-ingenol which are piscicidal constituents [10]. Recent research [11] on the chemical constituent of $E$. cotinifolia showed the presence of metalloprotease in the latex of E. cotinifolia.

This article describes the isolation, characterization, and determination of the structure of the new isolated compound from E. cotinifolia. The newly isolated compound was tested for antimicrobial activity against bacterial pathogens.

\section{Methods}

\section{Plant material}

Healthy and fresh leaves of Euphorbia cotinifolia were collected from local areas of Mysore and was used for the preparation of different solvent extracts. A voucher specimen of the plant material has been deposited in the Herbarium, Department Botany of University, and the voucher/specimen number is MGBH01.

\section{Extraction}

The test plants were thoroughly washed, shade dried, and powdered by using a warring blender. soxhlet extraction apparatus was used for extraction. One hundred grams of powdered leaf material was placed in a porous thimble of the apparatus in the upper chamber. Two hundred grams of extracting solvent was added to the lower boiling flask. The flask was heated by using a heating mantle controlled by a thermostat. Different solvents based on polarity from low to high in the following order of petroleum ether, chloroform, ethyl acetate, and methanol were filled in the round bottom flask, and the temperature was set based on the boiling point of the solvents. The solvent was heated to reflux and extracted. The material in the thimble was extracted with the different solvents successively till colorless extract was collected on the top of the extractor. The solvent extract collected after was concentrated separately under reduced pressure. After complete evaporation of the solvent from the extract, all solvent extracts were weighed 
and preserved in brown airtight bottle at $5{ }^{\circ} \mathrm{C}$ until further use.

\section{Phytochemical analysis}

Phytochemical analysis of all the solvent extracts was performed for the detection of active secondary metabolites or different constituents such as tannins, alkaloids, flavonoids, terpenoids, steroids, carbohydrates, proteins, and saponins. The dried extracts extracted by soxhlet apparatus were reconstituted in methanol, and each extract was subjected to standard phytochemical analysis according to the procedure described by Harborne [12].

\section{Human pathogenic bacteria}

Authentic and pure sample cultures of human pathogenic bacteria viz., Escherichia coli (E. coli) (MTCC 7410), Enterobacter aerogens (E. aerogens) (MTCC 7325), Bacillus cereus (B. cereus) (MTCC 1272), Bacillus subtilis (B. subtilis) (MTCC 121), Salmonella typhi (S. typhi) (MTCC 733), Klebsiella pneumoniae (K. pneumoniae) (MTCC 7407), and Staphylococcus aureus (S. aureus) (MTCC 7443) were used as test bacteria and obtained from Microbial Type Culture Collection (MTCC), Chandigarh, India. All the above bacterial samples were further sub-cultured on nutrient agar (NA) medium and frequently cultured. These bacterial cultures were used as test pathogens for the assay.

\section{Antibacterial activity}

Antibacterial activity of the fractions and compounds obtained was assayed by agar cup diffusion method [13]. On NA medium, $7 \mathrm{~mm}$ cork borer was used to make cups. Fifty microliters of 24-h bacterial culture containing $106 \mathrm{CFU} / \mathrm{ml}$ of bacteria was transferred and spread on the solidified media with a sterile swab which is moistened with the bacterial suspension. The fractions and compounds to be tested were reconstituted in methanol and prepared at a concentration of $100 \mathrm{mg} / \mathrm{ml}$. One hundred microliters of the fractions and compounds was placed in an individual cup and methanol of $100 \mu \mathrm{l}$ was placed in the central cup, which was considered as the negative control. All the plates were incubated at $37^{\circ} \mathrm{C}$ for $24 \mathrm{~h}$ and inhibition zone if any around the cups was measured in millimeters. For each treatment, a set of three replicates were maintained and all assays were repeated twice.

\section{Minimum inhibitory concentration (MIC)}

MIC was determined in 96-well sterile flat-bottom microtiter plates based on microdilution assay which is an automated turbidometric and colorimetric method as described by Kuntal Das [14]. Test bacterial inoculum was prepared from 24-h cultured bacteria and a suspension was made in sterile/saline water and adjusted to 0.5 McFarland standard solution turbidity.
E. cotinifolia methanol fractions and compounds were diluted to a concentration of $100 \mathrm{mg} / \mathrm{ml}$ which was used as a stock solution. The 96-well microtiter plates were prepared by transferring $200 \mu \mathrm{l}$ of broth and $100 \mu \mathrm{l}$ of the fractions/compound to the first well. A twofold serial dilution was made in the row up to 12-well and final concentrations from well 1 to 12 were $5-0.019 \mathrm{mg} / \mathrm{ml}$. A $10-\mu \mathrm{l}$ inoculum suspension of each bacterial strain was added to each well. The wells containing a solvent and nutrient broth with inoculum served as the negative control. The plates were incubated at $37^{\circ} \mathrm{C}$ for $24 \mathrm{~h}$, and the absorbance was measured at $620 \mathrm{~nm}$ using microplate reader (LT4000, LABTECH Instruments, UK). The minimum concentration that inhibited visible growth of the test bacteria was considered as the MIC based on the readings.

The minimum inhibitory concentration was also detected by adding TTC ( $10 \mu \mathrm{l} /$ well) (2, 3, 5-triphenyl tetrazolium chloride) dissolved in water (TTC $2 \mathrm{mg} / \mathrm{ml}$ ) and incubated under favorable conditions for $30 \mathrm{~min}$ [15]. Presence of viable organisms in the wells changed the dye to pink color. The minimum concentration at which there was a color change was taken as the MIC value. All MIC tests were repeated in triplicates.

\section{Isolation and characterization}

All the chemicals and solvents used in the present study were of Analytical Reagent grade. Solvents were used as supplied by commercial sources without any further purification. Elemental analysis was carried out on an Elemental Vario EL elemental analyzer. Column chromatographic separation was performed using Merck 7734 silica gel (60-120 mesh), and TLC experiment was carried out with pre-coated Merck silica gel 60 PF254 aluminum sheets; the spots were visualized under UV light. IR spectra were recorded on a JASCO FTIR-8400 spectrophotometer using Nujol mulls. The ${ }^{1} \mathrm{H}$ NMR spectra were recorded on a Varian AC 400 spectrometer instrument in $\mathrm{CDCl}_{3}$ using TMS as the internal standard. Low-resolution mass spectra were obtained on a Varian $1200 \mathrm{~L}$ model mass spectrometer (solvent: $\mathrm{CH}_{3} \mathrm{OH}$ ). Melting points were determined with a Buchi 530 melting point apparatus in open capillaries and are uncorrected.

The methanol extract $(4.1 \mathrm{~g})$ of E. cotinfolia was applied to silica gel column, eluting with gradient solvent system of $\mathrm{CHCl}_{3}-\mathrm{CH}_{3} \mathrm{OH}$ to give three fractions, $E$. cotinifolia methanol fraction [ECMF1 (80:20), ECMF2 (50:50), and ECMF3 (20:80)]. The structures of the compounds obtained from methanol extract (ECMF1 and ECMF2) were elucidated by spectroscopic techniques.

\section{Results}

\section{Phytochemical analysis}

The phytochemical analysis results of E. cotinifolia revealed the presence of tannins, steroids, flavonoids, terpenoids, 
Table 1 Phytochemical analysis of different solvent extracts of E. cotinifolia

\begin{tabular}{lllll}
\hline $\begin{array}{l}\text { Phytochemical } \\
\text { compounds }\end{array}$ & Extracts & Chloroform & Ethyl acetate & Methanol \\
\cline { 2 - 4 } & Petroleum ether & - & - & + \\
Alkaloids & - & - & + & + \\
Flavonoids & - & - & + & + \\
Terpenoids & - & - & + & + \\
Tannins & - & + & - & - \\
Steroids & + & + & - & - \\
Glycosides & + & + & - \\
Carbohydrates & + & - & - \\
Proteins & - & - & - \\
Saponins & - & &
\end{tabular}

$+=$ Present. $-=$ Absent

and glycosides in methanol and ethyl acetate extracts. Carbohydrates, steroids, and glycosides were present in petroleum ether and chloroform extracts. The phytochemical analysis of E. cotinifolia was studied and the results of these are given in Table 1.

\section{Antibacterial activity}

Antibacterial activity results of aqueous and different solvent extracts of $E$. cotinifolia against the test bacteria are presented in Table 2. Among the solvent extracts, methanol and ethyl acetate showed significant activity while negligible activity was found with chloroform extract. The inhibition range was recorded between 12-19 and $10-14 \mathrm{~mm}$ for methanol and ethyl acetate extracts, respectively. K. pneumoniae, E. aerogenes, and B. subtilis were highly susceptible to methanol extract with the maximum inhibition zone of $19 \mathrm{~mm}$. Ethyl acetate extract showed a uniform inhibition zone in the range of 10-14 $\mathrm{mm}$ against all the tested bacteria. Petroleum ether extract showed minimum activity. The MIC for susceptible test bacteria ranged from $0.312-1.25 \mathrm{mg} / \mathrm{ml}$ for methanol and ethyl acetate extracts. The minimum
MIC concentration was $0.312 \mathrm{mg} / \mathrm{ml}$ recorded for $B$. subtilis for both the extracts (Table 3)

Three fractions were obtained from methanol extract of $E$. cotinifolia and showed activity against all the tested human pathogenic bacteria. The inhibition zone measured for the new compounds was good but slightly lesser than that of its crude extract. The inhibition zone range against human pathogenic bacteria was 16.00$19.50 \mathrm{~mm}, 13.50-22.25 \mathrm{~mm}, 14.25-18.50 \mathrm{~mm}$, and 15.0 $\mathrm{mm}$ for ECMF1, ECMF2, ECMF3, and compound 1, respectively (Table 4). The MIC of the compound $\mathbf{1}$ against human pathogens was $78-833 \mu \mathrm{g} / \mathrm{ml}$ (Table 5).

\section{Characterization of active compounds of $E$. cotinifolia}

The methanol extract was subjected to a silica gel column, leading to the isolation of a new compound $\mathbf{1}$. Compound $\mathbf{1}$ was obtained as a pale yellow gum from $\mathrm{CHCl}_{3}-\mathrm{CH}_{3} \mathrm{OH}(80: 20)$ elute. The results obtained from the analytical and different spectral studies are given below: Compound 1. Anal. calc. for $\left(\mathrm{C}_{28} \mathrm{H}_{40} \mathrm{O}_{6}\right)$ : $\mathrm{C}$ 71.16; $\mathrm{H}$ 8.53. found: $\mathrm{C} 71.13 ; \mathrm{H}$ 8.51. IR (nujol, $\mathrm{cm}^{-1}$ ): 3364 , 1715, 1670, 1638. ${ }^{1} \mathrm{H}$ NMR $\left(300 \mathrm{MHz}, \mathrm{CDCl}_{3}\right) \delta: 0.80$ $(\mathrm{m}, 2 \mathrm{H}), 0.90(\mathrm{t}, 3 \mathrm{H}), 1.28(\mathrm{~s}, 6 \mathrm{H}), 1.50-1.80(\mathrm{bm}, 12 \mathrm{H})$,

Table 2 Antibacterial activity of different extracts of E. cotinifolia against some human pathogenic bacteria (in $\mathrm{mm}$ )

\begin{tabular}{|c|c|c|c|c|c|}
\hline Bacteria & Petroleum ether & Chloroform & Ethyl acetate & Methanol & Streptomycin \\
\hline Bacillus cereus & - & $8.75 \pm 0.47^{b}$ & $11.25 \pm 0.47^{\mathrm{ab}}$ & $12.25 \pm 0.50^{c}$ & $21.0 \pm 0.40^{b c}$ \\
\hline Bacillus subtilis & $8.25 \pm 0.2^{a}$ & $8.50 \pm 0.28^{b}$ & $12.75 \pm 0.62^{a}$ & $18.25 \pm 0.62^{b c}$ & $20.75 \pm 0.47^{b c}$ \\
\hline Escherichia.coli & - & $8.50 \pm 0.28^{b}$ & $10.75 \pm 0.25^{b}$ & $13.5 \pm 0.64^{a}$ & $23.75 \pm 0.47^{a}$ \\
\hline Enterobacter aerogenes & - & $10.25 \pm 0.2^{a}$ & $14.0 \pm 0.57^{a}$ & $19.25 \pm 0.62^{a}$ & $21.25 \pm 0.62^{b c}$ \\
\hline Klebsiella pneumoniae & $8.0 \pm 0.40^{a}$ & $8.75 \pm 0.25^{b}$ & $12.75 \pm 0.25^{a}$ & $19.0 \pm 0.40^{a}$ & $19.75 \pm 0.62^{c}$ \\
\hline Salmonella typhi & - & $8.25 \pm 0.25^{b}$ & $11.5 \pm 0.28^{\mathrm{ab}}$ & $16.0 \pm 0.40^{a}$ & $22.5 \pm 0.28^{a b}$ \\
\hline Staphylococcus aureus & - & $0.00 \pm 0$ & $10.75 \pm 0.25^{b}$ & $15.5 \pm 0.28^{a b}$ & $19.25 \pm 0.47^{c}$ \\
\hline
\end{tabular}

Values are means of four independent replicates. Figures followed by different letters in columns differ significantly when subjected to Tukey $(P<0.05)$. - means no activity 
Table 3 MIC of methanol and ethyl acetate extract $(\mathrm{mg} / \mathrm{mL})$ of E. cotinifolia against some human pathogenic bacteria

\begin{tabular}{llllllll}
\hline Bacteria & Bacillus cereus & Bacillus subtilis & Escherichia coli & $\begin{array}{l}\text { Enterobacter } \\
\text { aerogenes }\end{array}$ & $\begin{array}{l}\text { Klebsiella } \\
\text { pneumoniae }\end{array}$ & $\begin{array}{l}\text { Salmonella } \\
\text { typhi }\end{array}$ & $\begin{array}{l}\text { Staphylococcus } \\
\text { aureus }\end{array}$ \\
\hline MIC of methanol & 1.25 & 0.312 & 1.25 & 0.625 & 0.625 & 0.312 & 0.312 \\
MIC of ethyl acetate & 1.25 & 0.312 & 0.625 & 0.312 & 0.625 & 0.625 & 0.625 \\
\hline
\end{tabular}

$1.83(\mathrm{~s}, 3 \mathrm{H}), 2.52(\mathrm{~m}, 3 \mathrm{H}), 3.10(\mathrm{~s}, 2 \mathrm{H}), 3.35$ (bs, $1 \mathrm{H})$, $3.68(\mathrm{~s}, 3 \mathrm{H}), 3.86(\mathrm{~d}, 1 \mathrm{H}), 4.73,(\mathrm{~d}, 1 \mathrm{H}), 5.40(\mathrm{~s}, 1 \mathrm{H}), 5.80$ (d, $1 \mathrm{H}) .{ }^{13} \mathrm{C}$ NMR $\left(300 \mathrm{MHz}, \mathrm{CDCl}_{3}\right) \delta: 14,21,23,24$, $25,26,27,32,35,36,38,39,40,44,45,46,50,63,73$, $75,125,130,139,146,159,164,190 . \mathrm{MS}, \mathrm{m} / \mathrm{z}: 472\left(\mathrm{M}^{+}\right)$.

Based on the above data, the name of the compound $\mathbf{1}$ is given as 5-hydroxy-4-(2-methoxy-2-oxoethyl)-1,1,7-trimethyl11-oxo-1a,2,5,5a,6,9,10,10a-octahydro-1H-2,8a-methanocyclopenta [a]cyclopropa[e][10]annulen-6-yl heptanoate (Fig. 1; Tables 6 and 7).

With the study of the above analytical and spectral data, the following structures are proposed for the newly isolated compound 1 (Fig. 2).

\section{Discussion}

Plants are the reservoir of potent biochemicals which are obtained from different parts of the plant material. Herbal remedies from traditional folk medicine are the largely explored field for the development of new active drugs for chemotherapy, by which we can overcome the growing problems of drug resistance and can avoid the toxicity of the currently available antibiotics. The increasing importance in the possible application of the secondary metabolites for human and plant disease management has directed investigation towards the search of new sources of biologically active natural products.

The genus Euphorbia belonging to the family Euphorbiaceae is largest comprising about 2000 known species. Several researchers have shown the antibacterial and antioxidant activity of different Euphorbia sp. and the reports support the usage of these plants for the treatment of various diseases in traditional medicine [16-18].
The antibacterial activity of ethanol, chloroform, and hexane of extract of leaves of Euphorbia hirta extract was studied against some test bacteria and fungi such as Streptococcus mutans, Clostridium absonum, and Escherichia coli by disc diffusion method. The ethanolic leaf extract of Euphorbia hirta recorded a maximum zone of inhibition against in Clostridium (32 mm) [7, 19]. Phytochemical studies of Euphorbia milii showed the presence of cardiac glycosides, steroids/phytosterols, anthocyanin, terpenoids, flavonoids, and tannins, and the hexane extracts in the concentration of $5 \mu \mathrm{g} / \mathrm{ml}$ have shown considerable inhibition zone against Bacillus subtilis, Bacillus megaterium, Staphylococcus aureus, Entrococci, Escherichia coli, Proteus vulgaris, and Pusodomonas aeruginosa [20, 21].

E. cotinifolia, the test plant of this study, has shown molluscidal activity [22] and moderate antiviral and cytotoxic activity [23]. Rojas and co-workers [24] have evaluated antibacterial activity of $E$. cotinifolia, where the dried leaves were extracted with isopropyl alcohol and fractionated by column chromatography. Antibacterial activity against $S$. aureus, Enterococcus faecalis, E. coli, $K$. pneumoniae, and $P$. eruginosa was not reported by any of the fractions eluted from the column separation of E. cotinifolia extract. In the present investigation, soxhlet-based extraction successively from low polar to high polar solvents have been reported by the authors. These extracts have been subjected to antibacterial activity against E. coli, K. pneumonia, B. subtilis, $B$. cereus, S. typhi, E. aerogenes, and S. aureus. The toxicity of tannins on microorganisms functions either by direct action on the microbial membrane or by metal ion depletion [25].

Table 4 Antibacterial activity of methanol fractions and compound 1 of E. cotinifolia against human pathogenic bacteria (in mm)

\begin{tabular}{|c|c|c|c|c|c|c|c|}
\hline Bacteria & Solvent control & ECMF1 & ECMF2 & ECMF3 & Compound 1 & Streptomycin & Gentamicin \\
\hline B. cerus & 0.00 & $16.00 \pm 0.00$ & $18.50 \pm 0.50$ & $17.50 \pm 0.50$ & $15.00 \pm 0.00$ & $21.00 \pm 0.40$ & $24.30 \pm 0.33$ \\
\hline B. subtilis & 0.00 & $18.75 \pm 1.15$ & $19.25 \pm 0.57$ & $18.50 \pm 0.57$ & $18.67 \pm 0.50$ & $20.75 \pm 0.47$ & $29.30 \pm 0.88$ \\
\hline E. coil & 0.00 & $16.00 \pm 0.00$ & $13.50 \pm 0.57$ & $14.25 \pm 0.57$ & $16.50 \pm 0.00$ & $23.75 \pm 0.47$ & $22.00 \pm 0.57$ \\
\hline E. aerogens & 0.00 & $19.50 \pm 0.50$ & $22.00 \pm 0.57$ & $17.50 \pm 0.57$ & $20.00 \pm 0.50$ & $21.25 \pm 0.62$ & $23.60 \pm 0.88$ \\
\hline K. pneumonia & 0.00 & $18.00 \pm 1.00$ & $17.75 \pm 1.15$ & $18.00 \pm 0.57$ & $19.50 \pm 1.00$ & $19.75 \pm 0.62$ & $22.60 \pm 0.33$ \\
\hline S. typhi & 0.00 & $15.25 \pm 0.57$ & $14.50 \pm 0.57$ & $14.00 \pm 0.00$ & $17.00 \pm 1.00$ & $22.50 \pm 0.28$ & $23.60 \pm 0.66$ \\
\hline S. aureus & 0.00 & $17.00 \pm 0.00$ & $14.25 \pm 0.57$ & $13.50 \pm 1.50$ & $17.50 \pm 0.00$ & $19.25 \pm 0.47$ & $30.30 \pm 0.33$ \\
\hline
\end{tabular}

Values are mean of three independent replicates. \pm Standard deviation 
Table 5 MIC of methanol fractions and compound 1 of $E$. cotinifolia against human pathogenic bacteria (in $\mu \mathrm{g} / \mathrm{ml}$ )

\begin{tabular}{llll}
\hline Bacteria & ECMF1 & ECMF2 & Compound 1 \\
\hline B. cereus & 529 & 833 & 625 \\
B. subtilis & 208 & 156 & 169 \\
E. coil & 520 & 625 & 729 \\
E. aerogens & 78 & 169 & 110 \\
K. pneumonia & 156 & 140 & 156 \\
S. typhi & 625 & 416 & 833 \\
S. aureus & 208 & 315 & 416 \\
\hline
\end{tabular}

Values are mean of three independent replicates. \pm Standard deviation
Preliminary phytochemical analysis of methanol and ethyl acetate extracts of E. cotinifolia revealed the presence of tannins, terpenoids, flavonoids, and steroids. The structure of compounds of E. cotinifolia was elucidated by spectroscopic methods (IR, ${ }^{1} \mathrm{H}$ NMR, ${ }^{13} \mathrm{C}$ NMR, and MS) and compared with the earlier literature [13]. The IR spectrum of $\mathbf{1}$ displayed absorption bands corresponding to hydroxy $\left(3364 \mathrm{~cm}^{-1}\right)$ and carbonyl $(1715$, 1670 , and $1638 \mathrm{~cm}^{-1}$ ) functionalities. The ${ }^{1} \mathrm{H}$ NMR spectra of compound $\mathbf{1}$ revealed that the presence of hydroxyl and methyl ester groups, which displayed signals at $3.35(\mathrm{~s}, 1 \mathrm{H})$ and $3.68(\mathrm{~s}, 3 \mathrm{H})$, respectively. The spectrum displayed singlet at $1.28(\mathrm{~s}, 6 \mathrm{H})$ and $1.81(\mathrm{~s}$, $3 \mathrm{H})$ showing the presence of three methyl groups. In addition, a triplet peak at $0.89(\mathrm{t}, 3 \mathrm{H})$ revealed the

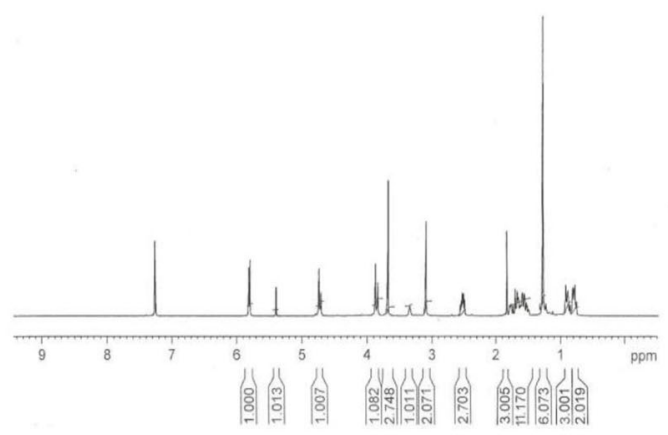

(a)

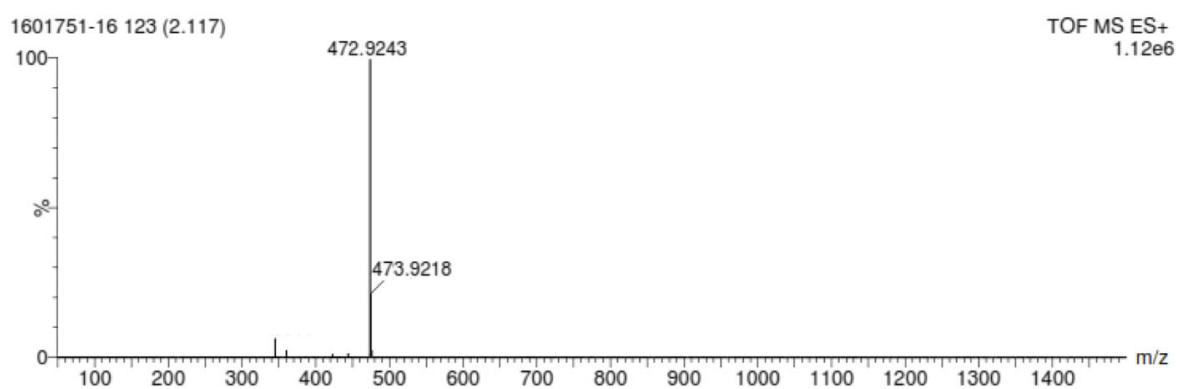

(b)

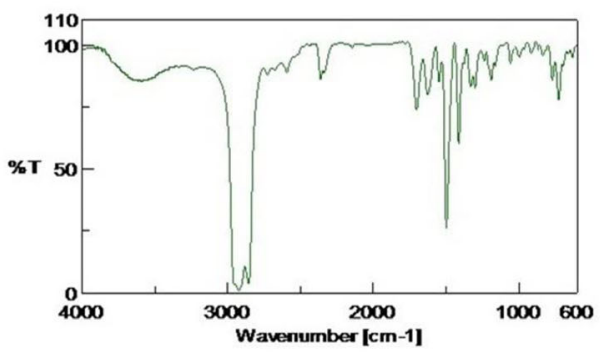

(c)

Fig. 1 The spectra of the newly isolated compound $\mathbf{1}$ from E. cotinifolia: a ${ }^{1} \mathrm{H}-\mathrm{NMR}, \mathbf{b}$ mass spectra, $\mathbf{c}$ infra-red 
Table $6{ }^{1} \mathrm{H}$ NMR in table format

\begin{tabular}{lll}
\hline SI. No. & Chemical shift values & $\begin{array}{l}\text { Position of proton } \\
\text { in the molecule }\end{array}$ \\
\hline$\underline{1}$ & $5.80(\mathrm{~d}, 1 \mathrm{H})$ & $\underline{1}$ \\
$\underline{2}$ & $5.40(\mathrm{~s}, 1 \mathrm{H})$ & $\underline{2}$ \\
$\underline{3}$ & 4.73 & $\underline{3}$ \\
$\underline{4}$ & 3.86 & $\underline{4}$ \\
$\underline{5}$ & $3.68(\mathrm{~s}, 3 \mathrm{H})$ & $\underline{5}$ \\
$\underline{6}$ & $3.35(\mathrm{bs}, 1 \mathrm{H})$ & $\underline{6}$ \\
$\underline{7}$ & $3.10(\mathrm{~s}, 2 \mathrm{H})$ & $\underline{7}$ \\
$\underline{8}$ & $2.52(\mathrm{~m}, 3 \mathrm{H})$ & $\underline{8}$ \\
$\underline{9}$ & $1.83(\mathrm{~s}, 3 \mathrm{H})$ & $\underline{9}$ \\
$\underline{10}$ & $1.50-1.80(\mathrm{bm}, 12 \mathrm{H})$ & $\underline{10}$ \\
$\underline{11}$ & $1.28(\mathrm{~s}, 6 \mathrm{H})$ & $\underline{11}$ \\
$\underline{12}$ & $0.90(\mathrm{t}, 3 \mathrm{H})$, & $\underline{12}$ \\
$\underline{\underline{13}}$ & $0.80(\mathrm{~m}, 2 \mathrm{H})$ & $\underline{13}$ \\
\hline
\end{tabular}

Table $7{ }^{13} \mathrm{C}$ NMR in table format

\begin{tabular}{|c|c|c|}
\hline SI. No. & Chemical shift values & $\begin{array}{l}\text { Position of carbon } \\
\text { in the molecule }\end{array}$ \\
\hline 1 & 190 & 1 \\
\hline$\underline{2}$ & 164 & $\underline{2}$ \\
\hline$\underline{3}$ & 159 & $\underline{3}$ \\
\hline$\underline{4}$ & 146 & $\underline{4}$ \\
\hline$\underline{5}$ & 139 & $\underline{5}$ \\
\hline$\underline{6}$ & 130 & $\underline{6}$ \\
\hline ? & 125 & $\underline{7}$ \\
\hline$\underline{8}$ & 75 & $\underline{8}$ \\
\hline$\underline{9}$ & 73 & $\underline{9}$ \\
\hline 10 & 63 & $\underline{10}$ \\
\hline 11 & 50 & 11 \\
\hline$\underline{12}$ & 46 & $\underline{12}$ \\
\hline$\underline{13}$ & 45 & $\underline{13}$ \\
\hline 14 & 44 & 14 \\
\hline 15 & 40 & $\underline{15}$ \\
\hline$\underline{16}$ & 39 & $\underline{16}$ \\
\hline 17 & 38 & 17 \\
\hline$\underline{18}$ & 36 & $\underline{18}$ \\
\hline$\underline{19}$ & 35 & $\underline{19}$ \\
\hline$\underline{20}$ & 32 & $\underline{20}$ \\
\hline$\underline{21}$ & 27 & $\underline{21}$ \\
\hline$\underline{22}$ & 26 & $\underline{22}$ \\
\hline$\underline{23}$ & 25 & $\underline{23}$ \\
\hline 24 & 24 & $\underline{24}$ \\
\hline$\underline{25}$ & 23 & $\underline{25}$ \\
\hline 26 & 21 & $\underline{26}$ \\
\hline 27 & 14 & $\underline{27}$ \\
\hline
\end{tabular}

presence of another methyl group which is linked to aliphatic carbon chain. The one singlet at $5.40(\mathrm{~s}, 1 \mathrm{H})$ and doublet at $5.80(\mathrm{~d}, 1 \mathrm{H})$ were due to the presence of olefin protons in the compound. The ${ }^{13} \mathrm{C}$ NMR of compound 1 recorded the presence of 27 signals, including three peaks at $\delta 159,164$, and 190, which were assigned to the carbonyl group. The mass spectrum of $\mathbf{1}$ displayed a molecular ion peak at $\mathrm{m} / \mathrm{z} 472$ corresponding to its molecular formula $\mathrm{C}_{28} \mathrm{H}_{40} \mathrm{O}_{6}$.

The genus Euphorbia contains the well-known diterpenoids such as jatrophene, lathyrane and myrisinane tigliane, ingenane, daphnane, segetane sesquiterpenoids, flavonoids (ruten kaempferol, myricetri, quercetin derivatives), volatile compounds (terpinene, linalool, $\alpha$ terpinol), tannins (euphorbins), triterpenoids (lupeol, betulin), and phytosterols ( $\beta$-sitosterol). These constituents were isolated from different parts of the Euphorbia species [4]. Many of the euphorbia compounds have been examined for their toxicity or their potential activity [26]. The literature review of E. cotinifolia has revealed the isolation and characterization of new ingenol esters from methanolic extract [10], which possess piscicidal constituents, two new ellagi tannins, and a trigalloylglucoseyl kaempferol from E. cotinifolia extract possessing antitumor and antioxidant activity indicating the potential of E. cotinifolia. The study by Runyoro and team [27] determined the antifungal activity and brine shrimp lethality of the latex, methanolic leaf, and stem bark extracts of Euphorbia cotinifolia and leaves extracts inhibited Trichophyton mentagrophytes, Trichophyton rubrum, and Aspergillus niger with inhibition zones of 12,17 , and $15 \mathrm{~mm}$, respectively, and $9 \mathrm{~mm}$ for both fungi with stem bark extracts, while the MICs ranged from 2.5 to $5 \mathrm{mg} / \mathrm{ml}$. In the present study, biologically active diterpene was isolated and the structures were elucidated.

\section{Conclusion}

In the present study, biologically active diterpene was isolated and the structures of the new diterpenoids isolated from $E$. cotinifolia were closely related to an ingenol ester in which the alkyl chain is differing in the present structure of active compound of methanol extract. Terpenoids are made up of isoprene units and mode of action of terpenes is not fully understood, but it is speculated to involve in membrane disruption by their liphophilic compound. Polycyclic diterpenoids with tigliane (phorbol esters), ingenane (ingenol esters), jatrophene, and laryprane skeletons are among the most studied diterpenoids isolated from Euphorbia species. Thus, in the present study, a terpenoid from E. cotinifolia has been reported with an antibacterial activity which could be a source of novel active molecules for drug development. 

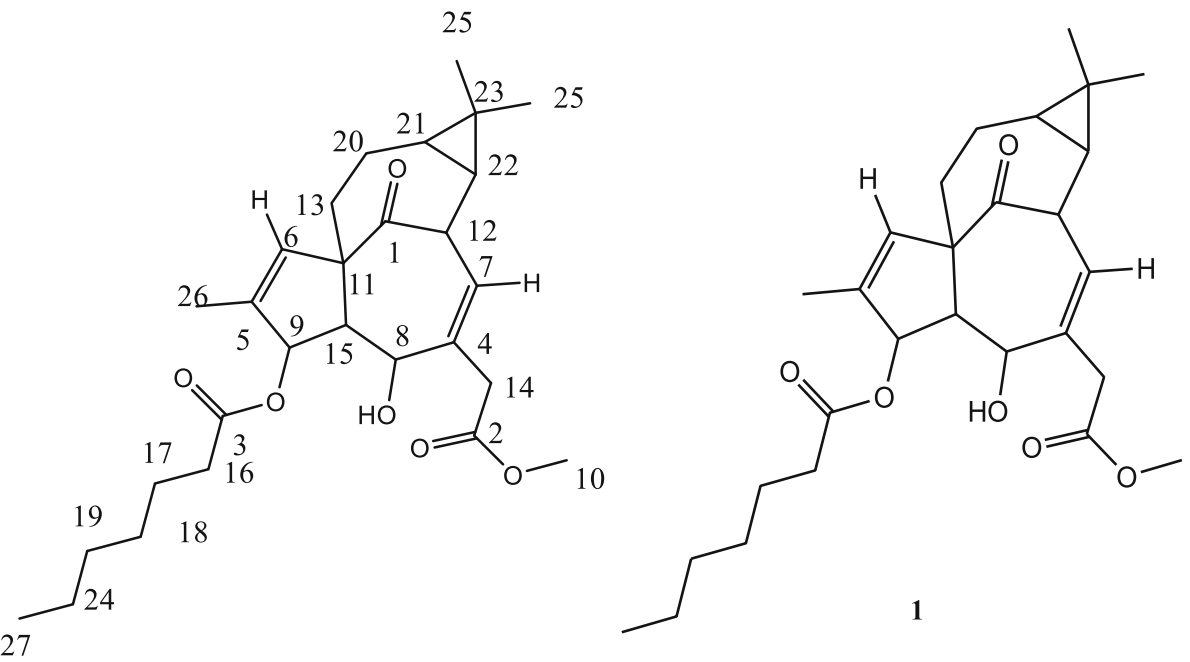

Fig. 2 Structures of newly isolated Compound $\mathbf{1}$ of E. cotinifolia

Currently, there is an increasing interest of plantbased or herbal medicine throughout the world. Exploitation of naturally available compounds from plants, which regulates the growth of undesirable microorganisms, would be a realistic and ecologically sound method for plant protection and will have a prominent role in the development of future commercial drugs.

\section{Supplementary Information}

The online version contains supplementary material available at https://doi. org/10.1186/s43094-020-00160-9.

\section{Additional file 1.}

\section{Abbreviations}

MTCC: Microbial Type Culture Collection; NA: Nutrient agar; MIC: Minimum inhibitory concentration; ECMF: Euphorbia cotinifolia methanol fractions; CFU: Colony forming units; TTC: 2, 3, 5-triphenyl tetrazolium chloride; UV: Ultraviolet; H NMR: Proton nuclear magnetic resonance; C NMR: Carbon nuclear magnetic resonance; TMS: Tetramethysilane; MS: Mass spectra; IR: Infra-red

\section{Acknowledgements}

One of the authors, B. Jayalakshmi, is thankful to the University Grants Commission, New Delhi, for awarding FIP-Teacher Fellowship and Department of Collegiate Education, Govt. of Karnataka, Bangalore, and also the University of Mysore, Mysore, for providing the laboratory facilities.

\section{Plant authentication}

The taxonomists in the Department of studies in Botany, University of Mysore have identified the plant. A voucher specimen of the plant has been deposited in the Herbarium, Department of Studies in Botany, University of Mysore, Mysore. India and voucher /specimen number is assigned as MGBH01.

\section{Authors' contributions}

BJL conceived, designed, and performed the above research work. KNA contributed reagents/materials/analysis tools and designed the experiments. KAR analyzed the data. All authors have read and approved the manuscript

\section{Funding}

The research did not receive any funds from any source
Availability of data and materials

All data and materials are available upon request

Ethics approval and consent to participate

Not applicable

\section{Consent for publication}

Not applicable

\section{Competing interests}

No competing interests to declare.

\section{Author details}

${ }^{1}$ Post Graduate Department of Botany, Maharani's Science College for Women, Mysore, Karnataka 570 006, India. ${ }^{2}$ Department of Water \& Health, Faculty of Life Sciences, JSS Academy of Higher Education and Research, Sri Shivarathreeshwara Nagara, Mysuru, Karnataka, India. ${ }^{3}$ Applied Plant Pathology Laboratory, Department of Studies in Botany, University of Mysore, Manasagangotri, Mysore, Karnataka 570 006, India.

Received: 17 April 2020 Accepted: 21 December 2020

Published online: 07 January 2021

\section{References}

1. Cowan MM (1999) Plant products as antimicrobial agents. Clin Microbio Rev 12:564-582

2. Varma JM, Tripathi VJ, Ram VB, Pandey NK, Dubey (2002) Y-Asarone- the fungitoxic principle of the essential oil of Caesulia axillaris. World J Microbiol Biotechnol 18:277-279

3. Alagesaboopathi C (2011) Antimicrobial screening of selected medicinal plants in Tamilnadu, India. Afr J Microbiol Res 5:617-621

4. Ozbilgin S, Citoglu GS (2012) Uses of some euphorbia species in traditional medicine in Turkey and their biological activities. Turkish J Pharm Sci 9:241-256

5. Maneesha S, Sudha (2018) Evaluation of phytochemical and antibacterial activity of Euphorbiaceae members against human pathogens. Intl J Recent Scient Res 9(8):28534-28538

6. Singariya P, Kumar MK, Kumar P (2018) Comparative study of antibacterial properties of flavonoids of leaves from different cactus, perennial grasses and medicinal plant. Asian J Pharm Res Dev 6(3):32-41

7. Reena G, Jitendra G (2019) Investigation of antimicrobial activity of euphorbia hirta leaves. Int J Life Sci Pharma Res 9(3):32-37

8. Webster G (1994) Systematic of the. Euphorbiaceae: Ann Missouri Bot Gard 81(1):33-144 
9. Pereira JP, De Souza CP, Mendes NM (1978) Molluscicidal properties of the Euphorbia cotinifolia L. Revista Brasileira de Pesquisas Medicas e Biologica's 11:345-351

10. Hirota MH, Yoshinori OO, Koshimizu K (1980) New ingenol-esters as piscicidal constituents of Euphorbia cotinifolia L. Agric Biol Chem 44: 1351-1356

11. Kumar R, Kunwar AS, Ritu T, Medicherla VJ (2011) Biochemical and spectroscopic characterization of a novel metalloprotease, cotinifolin from an antiviral plant shrub: Euphorbia cotinifolia. Plt Physio Biochem $49: 721-728$

12. Harborne JB (1998) Phytochemical methods. Chapman and Hall Publications, London, pp 7-8

13. Perez CM, Bazerque PP (1990) An antibiotic assay by agar well diffusion method. Acta Biologica Et Medica Experimentalis 15:113-115

14. Das K, Tiwari RKS, Shrivastava DK (2010) Techniques for evaluation of medicinal plant products as antimicrobial agent: current methods and future trends. J Med Plant Res 4:104-111

15. Qaiyami S (2007) Macro and microdilution methods of antimicrobial susceptibility testing. In: Schwalbe R, Steele-Moore L, Goodwin AC (eds) Antimicrobial susceptibility testing protocols. Taylor \& Francis, New York, pp 75-81

16. Hohmann J, Re-dei D, Forgo P, Molna'r J, Dombi G, Zorig T (2003) Jatrophane diterpenoids from Euphorbia mongolica as modulators of the multidrug resistance of L5128 mouse lymphoma cells. J Nat Prod 66:976-979

17. Haba H, Lavaud C, Harkat H, A. Alabdul L, Marcourt M, Benkhaled (2007) Diterpenoids and triterpenoids from euphorbia guyoniana. Phytochem. 68: 1255-1260

18. Hore S, Ahuja V, Mehta G, Kumar P, Pandey S, Ahmad A (2006) Effect of aqueous Euphorbia hirta leaf extract on gastrointestinal motility. Fitoterapia. 77:35-38

19. Divya G, Kumar M, Vishal G (2018) An in vitro investigation of antimicrobial efficacy of Euphorbia hirta and Murraya koenigii against selected pathogenic microorganisms. Asian J Pharm Clin Res 11(5):359-363

20. Vyas M, Desai B (2018) Phytochemical screening and antimicrobial activity of flower extract of Euphorbia milii. BMR Phytomed 4(1):1-6

21. Jyothi TM, Shankariah MM, Prabhu K, Lakshminarasu S, Srinivasa GM, Ramachandra SS (2008) Hepatoprotective and antioxidant activity of Euphorbia tirucalli. Iran J Pharmacol Ther 7:25-30

22. Percia JP, de Souza Mendes NM (1978) Molluscidal properties of the Euphorbia cotonifolia L, rev. Bras Pesqui Med Biol 11:345-351

23. Galvis Betancur LA, Morales GE, Forero JE, Roldan J (2002) Cytotoxic and antiviral activities of Colombian medicinal plant extracts of the genus. Mem Inst Oswaldo Cruz Rio de Janeiro 97:541-546

24. Rojas J, Morales A, Rondon MGM (2008) Analysis POR CG/EM DE Hidrocarburos Y Compuestos Terpenicos EN LAS Especies Euphorbia caracasana Boiss Y Euphorbia cotinifolia L. (Euphorbiaceae). Revista Latinoamericana de Quimica 36:22-28

25. McDonald M, Mila I, Scalbert (1996) Precipitation of metal ions by plant polyphenols: optimal conditions and origin of precipitation. J Agric Food Chem 44:599-606

26. Tang Q, Su Z, Han Z, Ma X, Xu D, Liang Y, Cao H, Wang X, Qu X, Hoffman A, Liu H, Gu D, Qiu D (2012) LC-MS method for detecting prostratin in plant extracts and identification of a high-yielding population of euphorbia fischeriana. Phytochem Lett 5:214-218

27. Runyoro DKB, Ngassapa OD, Nondo RSO, Melkiory P (2017) Antifungal activity against onychomycosis causative fungi and brine shrimp lethality of a Tanzanian ornamental plant Euphorbia cotinifolia L. (Euphorbiaceae). J Pharm Sci Res 9(1):63-67

\section{Publisher's Note}

Springer Nature remains neutral with regard to jurisdictional claims in published maps and institutional affiliations.

\section{Submit your manuscript to a SpringerOpen ${ }^{\circ}$ journal and benefit from:}

- Convenient online submission

- Rigorous peer review

- Open access: articles freely available online

- High visibility within the field

- Retaining the copyright to your article

Submit your next manuscript at $\boldsymbol{\nabla}$ springeropen.com 